\title{
Respon Serapan Hara Makro-Mikro dan Produksi Tanaman Jagung (Zea mays L.) Terhadap Pemupukan Nitrogen dan Praktik Olah Tanah Jangka Panjang
}

\author{
Response of Macro-Micro Nutrient Uptake and Production of Corn (Zea mays L.) \\ Against Nitrogen Fertilization and Practice Long-term Land Cultivation \\ Debby Agsari $^{1 \star}$, Muhajir Utomo ${ }^{2}$, Kuswanta F Hidayat $^{3}$, Ainin Niswati ${ }^{2}$ \\ 1Jurusan Magister Agronomi, Fakultas Pertanian, Universitas Lampung \\ 2Jurusan IImu Tanah, Fakultas Pertanian, Universitas Lampung \\ ${ }^{3}$ Jurusan Agroteknologi, Fakultas Pertanian, Universitas Lampung \\ Jl. Sumantri Brojonegoro 1, Bandar Lampung, 35145, Lampung, Indonesia \\ *Email: agsaridebby1608@gmail.com, mutomo2011@gmail.com
}

Disubmit: 14 September 2019 Direvisi: 23 Desember 2019 Diterima: 18 Januari 2020

\begin{abstract}
Abstrak: Tujuan penelitian ini untuk mengevaluasi pengaruh pemupukan $\mathrm{N}$ dan sistem olah tanah jangka panjang tahun ke-29 terhadap serapan hara makro-mikro dan produksi tanaman jagung. Penelitian jangka panjang yang dimulai sejak 1987 ini dilakukan di Politeknik Negeri Lampung pada Oktober 2016 - Januari 2017. Percobaan faktorial disusun dalam rancangan acak kelompok dengan empat ulangan. Faktor pertama adalah

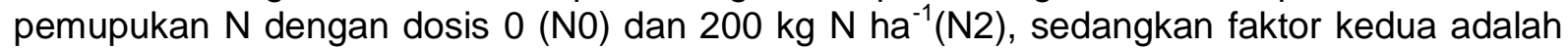
sistem olah tanah yaitu olah tanah intensif (T2), olah tanah minimum (T1) dan tanpa olah tanah (T0). Hasil penelitian menunjukkan bahwa perlakuan N2 meningkatkan serapan hara makro dan mikro lebih tinggi dibandingkan tanpa pemupukan $\mathrm{N}$, sedangkan praktik olah tanah tidak berpengaruh terhadap peningkatan serapan hara, kecuali B. Interaksi N2 dan T1 menghasilkan produksi jagung dan serapan hara S lebih tinggi dibandingkan interaksi N2 dengan T2 $(p<0,05)$, namun sama dengan interaksi N2 dan T0. Praktik olah tanah minimum jangka panjang menghasilkan efisiensi serapan nitrogen (ESN) lebih tinggi dibandingkan T0 dan T2 yaitu sebesar 16,28\%. Sementara nilai Relative Agronomic Effectivenes (RAE) N2 dan perlakuan sistem olah tanah jangka panjang menghasilkan nilai RAE berturut-turut sebesar 3,50; 9,50 dan 19,5 kg pipilan jagung per $1 \mathrm{~kg}$ pupuk $\mathrm{N}$ pada T2, T1 dan T0.
\end{abstract}

Kata kunci: Eefisiensi N, olah tanah konservasi, pemupukan N, hara makro-mikro.

Abstract: The aims of the study were to determine the effect of long-term $N$ fertilization and tillage systems on makro and micro nutrient uptakes, corn yield and relative agronomic effectiveness (RAE). This long-term study which initiated since 1987 was carried out at Politecnic Negeri Lampung, Bandar Lampung from October 2016 to January 2017. A factorial experiment was arranged in a randomized block design with four replications. The first factor was long-term $N$ fertilization with rates of $\mathrm{O}$ (N0) and $200 \mathrm{~kg} \mathrm{~N} \mathrm{ha}^{-1}$ (N2), while the second factor was tillage practices namely intensive tillage (T2), minimum tillage (T1) and no-tillage (T0). The results showed that after 29 years of cropping, N2 treatment had macro and micro nutrient uptakes higher than NO $(p<0.05)$. In contrast to $N$ fertilization, tillage practices did not affect nutrient uptakes except $B$ uptakes. The interaction between treatments of N2 and T1 produced corn production and $S$ uptake higher compared to the interaction of N2 and T2 $(p<0.05)$, but the same as the interaction of 22 and T0. The long-term T1 produced Nitrogen Use Efficiency (NUE) as much as $16.3 \%$, it was higher than those of TO and T2. While with $200 \mathrm{~kg} \mathrm{~N} \mathrm{ha}^{-1}$, long-term tillage practices produced Relative Agronomic Effectiveness (RAE) as much as 3.50, 9.50 and $19.5 \mathrm{~kg}$ corm grain per $1 \mathrm{~kg}$ of $\mathrm{N}$ fertilizer of T2, T1 ant T0, respectively.

Keywords: Conservation tillage, $N$ fertilization, macro and micro nutrient, nutrient use efficiency 


\section{PENDAHULUAN}

Kebutuhan dan konsumsi jagung di Indonesia terus meningkat seiring dengan meningkatnya jumlah penduduk dan industri yang menggunakan jagung sebagai bahan baku, seperti industri makanan dan pakan ternak. Produksi jagung di Indonesia pada tahun 2015 sebesar 1,50 juta ton pipilan kering, telah mengalami penurunan sebanyak 216,59 ribu ton (12,60\%) dibandingkan tahun 2014. Penurunan produksi terjadi karena penurunan luas panen sebesar 45,36 ribu hektar $(13,39 \%)$ (BPS, 2015).

Kendala yang saat ini dihadapi adalah kurangnya ketersediaan areal untuk aktivitas budidaya jagung. Salah satu strategi untuk meningkatkan kebutuhan pangan nasional dengan mengoptimalkan fungsi lahan kering sebagai lahan alternatif, karena lahan kering memiliki potensi dan peluang yang besar untuk memenuhi kebutuhan pangan nasional.

Salah satu teknik budidaya yang digunakan pada lahan kering yaitu teknologi tanpa olah tanah. Teknik pengolahan tanpa olah tanah memberikan banyak keuntungan bagi tanah antara lain : menjaga/menghindari erosi yang mengakibatkan terjadinya kehilangan lapisan top soil, mempertahankan kelembaban tanah dan mengurangi penguapan sehingga tanah tidak keras, selain itu serasah juga dapat menambah bahan organik bagi tanah. Hal ini tentu dapat membantu tanah untuk beristirahat dan memugarkan kualitas tanah itu sendiri. Salah satu keunggulan tanpa olah tanah adalah pengembalian bahan organik tanah dengan pemberian mulsa. Bahan organik tanah memiliki peranan yang sangat penting dalam memperbaiki sifat-sifat tanah (Utomo, 2012).

Kegiatan budidaya dan pengolahan lahan tidak dapat dipisahkan dengan perlakuan pemupukan. Pemupukan merupakan salah satu faktor penentu dalam upaya meningkatkan produktivitas tanaman. Unsur hara $\mathrm{N}$ sangat penting untuk pertumbuhan dan perkembangan tanaman. Unsur hara $\mathrm{N}$ merupakan bahan pembangun protein, asam nukleat, enzim, nukleoprotein dan alkaloid. Sementara itu defisiensi $\mathrm{N}$ akan membatasi pembesaran dan pembelahan sel (Napitupulu dan Winarto, 2010).

Jenis tanah juga sangat mempengaruhi segala aspek di dalam maupun di permukaan tanah. Tanah Ultisol mempunyai sebaran yang sangat luas, meliputi hampir 25\% dari total daratan Indonesia (Prasetyo dan Suriadikarta, 2006). Beberapa kendala yang umum pada tanah Ultisol adalah tanah asam, $\mathrm{pH}$ rata-rata < 4,50; kejenuhan Al tinggi, miskin kandungan hara makro-mikro terutama $\mathrm{P}, \mathrm{K}, \mathrm{Ca}$, $\mathrm{Mg}$ dan kandungan bahan organiknya rendah; selanjutnya kandungan hara pada tanah Ultisol umumnya rendah karena pencucian basa berlangsung intensif, dan kandungan bahan organik rendah karena proses dekomposisi berjalan cepat dan sebagian terbawa erosi.

Oleh karena itu, peningkatan produktivitas tanah Ultisol dapat dilakukan melalui perbaikan tanah (ameliorasi), pemupukan, dan pemberian bahan organik, serta penerapan sistem tanpa olah tanah (Prasetyo dan Suriadikarta, 2006). Penelitian ini dilakukan untuk mengevaluasi pengaruh pemupukan $\mathrm{N}$ dan berbagai sistem olah tanah jangka panjang terhadap serapan hara dan produksi tanaman jagung. 


\section{METODE PENELITIAN}

Penelitian dilakukan pada bulan Oktober 2016 hingga Januari 2017. Penelitian ini dilaksanakan di kebun percobaan Politeknik NegeriLampung $\left(105^{\circ} 13^{\prime} 45,5^{\prime \prime}\right.$ $\left.{ }^{1} 05^{\circ} 13^{\prime} 48,0^{\prime \prime} \mathrm{E}, \quad 5^{\circ} 21^{\prime} 19,6^{\prime \prime}{ }^{\prime 1} 5^{\circ} 21^{\prime} 19,7^{\prime \prime} \mathrm{S}\right)$. Penelitian ini merupakan bagian dari penelitian sistem olah tanah jangka panjang yang dimulai pada bulan Februari 1987 dengan pola rotasi tanaman serealia (jagung dan padi gogo), legum (kedelai, kacang tanah dan kacang hijau) kemudian diberakan (Utomo, Suprapto. dan Sunyoto, 1989).

Percobaan ini dirancang sama dengan percobaan awal tahun 1987 yaitu dilakukan secara faktorial, dengan Rancangan Acak Kelompok dan 4 ulangan, seperti yang dilaporkan oleh (Utomo, Suprapto. dan Sunyoto, 1989). Faktor pertama adalah perlakuan sistem olah tanah jangka panjang, yaitu T2 : olah tanah intensif (OTI), T1 : olah tanah minimum (T1), T0 : tanpa olah tanah (TOT), dan faktor kedua pemupukan $\mathrm{N}$, dengan dosis $\mathrm{N} 0: 0 \mathrm{~kg} \mathrm{~N} \mathrm{ha}^{-1}, \mathrm{~N} 2: 200 \mathrm{~kg} \mathrm{~N}^{-1}$. Pupuk $\mathrm{N}$ yang digunakan adalah Urea, sedangkan sebagai pupuk dasar SP-36 $100 \mathrm{~kg} \mathrm{ha}^{-1}$ dan KCl $50 \mathrm{~kg} \mathrm{ha}^{-1}$. Data yang telah dihasilkan dirata-ratakan, kemudian dilakukan uji homogenitas data dengan uji Bartlet dan uji aditivitas diuji dengan uji Tukey. Selanjutnya data di analisis ragam, analisis lanjutan dengan menggunakan uji BNJ pada taraf $5 \%$.

Sampel tanah diambil pada akhir pertanaman untuk pengamatan hara makromikro dan sifat-sifat tanah pada kedalaman $0-20 \mathrm{~cm}$. Sebelum analisis, sampel tanah dikering anginkan, ditumbuk dan diayak. Tanah tersebut akan diuji sifat kimia tanahnya. Untuk analisis hara tanaman, sampel tanaman diambil saat fase vegetatif maksimum (menjelang jagung berbunga), luas panen 1,5 m x 2,5 m. Sampel tanaman kemudian dioven dengan suhu $70^{\circ} \mathrm{C}$ selama $2-3$ hari untuk selanjutnya sampel digiling dan dianalisis. Pemanenan jagung dilakukan setelah masak fisiologis (sekitar 3 bulan) dengan luas panen 1,5 m x 2,5 m. Saat panen, kadar air jagung pipilan diukur dengan Moister Seed Tester, kemudian kadar airnya dikonversi ke $14 \%$.

Efisiensi serapan $\mathrm{N}$ tanaman dihitung untuk melihat berapa persen serapan $\mathrm{N}$ yang dimanfaatkan tanaman untuk pertumbuhan. Efisiensi serapan $\mathrm{N}$ dihitung menggunakan rumus :

Keterangan:

$$
\mathrm{ESN}=\frac{\mathrm{SP}-\mathrm{SK}}{H P} \times 100 \%
$$

SP : Serapan N pada tanaman yang di pupuk $\left(\mathrm{kg} \mathrm{N} \mathrm{ha}^{-1}\right)$

SK : Serapan N pada tanaman yang tidak dipupuk $\left(\mathrm{kg} \mathrm{N} \mathrm{ha}^{-1}\right)$

HP : Pupuk N yang diberikan ( $\mathrm{kg} \mathrm{N}^{-1}{ }^{-1}$ ) (Habbib et al. 2016).

Relative Agronomic Effectiveness (RAE) adalah perbandingan antara kenaikan hasil karena penggunaan pupuk yang dengan kenaikan hasil pada tanaman yang tidak dipupukdikalikan $100 \%$. Uji efektivitas dihitung dengan menggunakan RAE dengan rumus:

Keterangan :

$$
\mathrm{RAE}=\frac{D-K}{S}
$$

$\mathrm{D}:$ Produksi tanaman jagung yang di pupuk $\left(\mathrm{kg} \mathrm{ha}^{-1}\right)$

$\mathrm{K}$ : Produksi tanaman jagung kontrol

$\left(\mathrm{kg} \mathrm{ha}^{-1}\right)$

S : Pupuk yang digunakan (kg ha-1) (Mackay, Syers and Gregg, 1984). 
HASIL DAN PEMBAHASAN

\section{Analisis Tanah Akhir}

Kandungan $\mathrm{pH}$ tanah akhir penelitian ini berkisar antara 5,76-6,11 dengan kriteria agak masam, kapasitas tukar kation (KTK) tanah tergolong sangat rendah dengan kisaran 6,26-6,42 $\mathrm{cmol}_{\mathrm{c}} \mathrm{kg}^{-1}$ dan kandungan C-organik berkisar antara 1,45${ }^{1}, 58 \%$ juga tergolong rendah (Tabel 1). Kondisi ini umum ditemukan pada tanah Ultisol yang terletak pada zona iklim tropis dengan curah hujan cukup tinggi, hal tersebut mengakibatkan pencucian basa berlangsung intensif dan menyebabkan $\mathrm{pH}$ tanah menjadi masam, selanjutnya proses dekomposisi pada tanah Ultisol termasuk cepat dan mudah terbawa erosi hal ini mengakibatkan kandungan C-organik dan kemampuan kapasitas tukar kation pada tanah Ultisol umumnya rendah (Prasetyo dan Suriadikarta, 2006).

Kandungan $\mathrm{N}$-total, $\mathrm{P}$-tersedia dan $\mathrm{K}$ tanah tergolong rendah pada seluruh perlakuan (Tabel 1). Pupuk urea termasuk pupuk yang higrokopis (menarik uap air) pada kelembaban $73 \%$ sehingga urea mudah larut dalam air dan mudah diserap tanaman (Lingga dan Marsono, 2008). Rendahnya kandungan N-total tanah dapat terjadi akibat pencucian, erosi, diangkut oleh tanaman serta terjadi melalui proses penguapan.

Ketersediaan $\mathrm{P}$ dipengaruhi oleh kemasaman tanah, senyawa $\mathrm{Fe}, \mathrm{Al}$ dan $\mathrm{Ca}$ terlarut, tingkat dekomposisi bahan organik dan aktivitas mikroorganisme (Hardjowigeno ,2007). Unsur hara dalam tanah terdiri dari berbagai bentuk dengan kecepatan ketersediannya beragam, fosfor merupakan unsur yang tidak mudah larut sehingga ketersediannya relatif rendah (Salam, 2012). Pada perlakuan N0T0 pemberian bahan organik dapat menjadi salah satu alasan mengapa kandungan hara $\mathrm{K}$ lebih tinggi dibandingkan perlakuan yang lain. Unsur $\mathrm{K}$ dalam tanah terurai secara perlahan (lebih lambat dibandingkan unsur $\mathrm{N}$ ), sehingga residu unsur K dapat lebih besar didalam tanah (Nurahmi, 2010).

Tabel 1. Sifat kimia tanah akhir tahun tanam ke-29 kedalaman 0-20 cm.

\begin{tabular}{|c|c|c|c|c|c|c|}
\hline Perlakuan & $\begin{array}{c}\mathrm{N}- \\
\text { total } \\
(\%)\end{array}$ & $\begin{array}{c}\text { P. } \\
\text { tersedia } \\
\left(\mathrm{mg} \mathrm{kg}^{-1)}\right.\end{array}$ & $\begin{array}{c}\mathrm{K} \\
\left(\mathrm{cmol}_{\mathrm{c}}\right. \\
\left.\mathrm{kg}^{-1}\right)\end{array}$ & $\begin{array}{c}\text { C- } \\
\text { organik } \\
(\%)\end{array}$ & $\underset{\left(\mathrm{H}_{2} \mathrm{O}\right)}{\mathrm{pH}}$ & $\begin{array}{c}\text { KTK } \\
\left(\mathrm{mg} \mathrm{kg}^{-1}\right)\end{array}$ \\
\hline N0T2 & $0,13^{(R)}$ & $2,14^{(\mathrm{SR})}$ & $0,17^{(\mathrm{SR})}$ & $1,45^{(\mathrm{R})}$ & $6,02^{(\mathrm{AM})}$ & $6,24^{(\mathrm{SR})}$ \\
\hline N0T1 & $0,15^{(\mathrm{R})}$ & $2,55^{(\mathrm{SR})}$ & $0,29^{(\mathrm{R})}$ & $1,58^{(\mathrm{R})}$ & $6,05^{(\mathrm{AM})}$ & $6,42^{(\mathrm{SR})}$ \\
\hline NOTO & $0,17^{(\mathrm{R})}$ & $2,41^{(\mathrm{SR})}$ & $0,46^{(S)}$ & $1,47^{(\mathrm{R})}$ & $6,11^{(\mathrm{AM})}$ & $6,31^{(\mathrm{SR})}$ \\
\hline N2T2 & $0,13^{(\mathrm{R})}$ & $2,17^{(\mathrm{SR})}$ & $0,19^{(\mathrm{R})}$ & $1,46^{(\mathrm{R})}$ & $5,80^{(\mathrm{AM})}$ & $6,37^{(\mathrm{SR})}$ \\
\hline N2T1 & $0,14^{(\mathrm{R})}$ & $2,11^{\text {(SR) }}$ & $0,28^{(\mathrm{R})}$ & $1,54^{(\mathrm{R})}$ & $5,76^{(\mathrm{AM})}$ & $6,31^{(\mathrm{SR})}$ \\
\hline N2TO & $0,15^{(\mathrm{R})}$ & $2,12^{(\mathrm{SR})}$ & $0,23^{(\mathrm{R})}$ & $1,50^{(\mathrm{R})}$ & $5,84^{(\mathrm{AM})}$ & $6,26^{(\mathrm{SR})}$ \\
\hline
\end{tabular}

Keterangan: T2 : Olah tanah intensif; T1 : Olah tanah minimum; T0 : Tanpa olah tanah; N0 : $0 \mathrm{~kg} \mathrm{~N}^{-1}$; $\mathrm{N} 2: 200 \mathrm{~kg} \mathrm{~N} \mathrm{ha}^{-1}$, AM : agak masam, SR : sangat rendah,R : rendah, S : sedang, T : tinggi, ST: sangat tinggi (Hardjowigeno,2007). 
Tabel 2. Pengaruh pemupukan nitrogen dan praktik olah tanah jangka panjang terhadap produksi tanaman jagung.

\begin{tabular}{|c|c|c|c|}
\hline \multirow{3}{*}{ Pemupukan N } & \multicolumn{3}{|c|}{ Sistem Olah Tanah } \\
\hline & T2 & $\mathrm{T} 1$ & T0 \\
\hline & \multicolumn{3}{|c|}{$\left(\mathrm{t} \mathrm{ha}^{-1}\right)$} \\
\hline $0 \mathrm{~kg} \mathrm{~N} \mathrm{ha}^{-1}$ & $4,65 a$ & $5,25 a$ & $2,90 \mathrm{a}$ \\
\hline \multirow[t]{2}{*}{$200 \mathrm{~kg} \mathrm{~N} \mathrm{ha}^{-1}$} & $\begin{array}{c}A \\
5,35 \mathrm{a}\end{array}$ & $\begin{array}{c}\mathrm{A} \\
7,15 \mathrm{a}\end{array}$ & $\begin{array}{c}A \\
6,80 \mathrm{a}\end{array}$ \\
\hline & A & A & B \\
\hline BNJ 5\% & \multicolumn{3}{|c|}{2,51} \\
\hline
\end{tabular}

Perlakuan N2T1 (200 kg N ha ${ }^{-1}$; Olah tanah minimum) menghasilkan produksi jagung sebesar 7,15 $\mathrm{t} \mathrm{ha}^{-1}$ namun tidak berbeda dengan perlakuan N0T1 (0 kg N ha 1; Olah tanah minimum) sebesar $5,25 \mathrm{t} \mathrm{ha}^{-1}$ (Tabel 2). Sementara itu pola respon produksi tanaman jagung menunjukkan bahwa bobot produksi perlakuan N2T0 (200 $\mathrm{kg} \mathrm{N}$ ha $^{-1}$; Tanpa olah tanah) mengahasilkan perlakuan yang lebih efisien dibandingkan NOTO (0 kg N ha ${ }^{-1}$; Tanpa olah tanah), namun hasil produksi tertinggi terdapat pada N2T1 sebesar 7,15 t ha-1 (Tabel 2). Sedangkan hasil analisis ragam bobot brangkasan jagung menunjukkan hanya perlakuan pemupukan $\mathrm{N}$ yang memberikan pengaruh terhadap hasil brangkasan. Brangkasan jagung tertinggi terdapat pada perlakuan pemupukan nitrogen tinggi (N2) (Gambar 2).

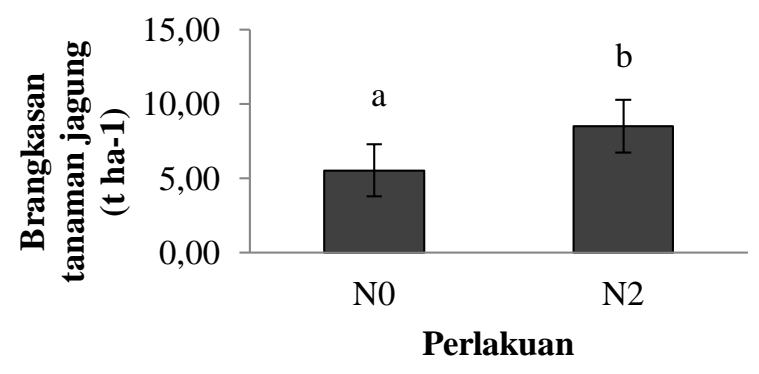

Gambar 1. Pengaruh perlakuan pemupukan nitrogen jangka panjang terhadap brangkasan tanaman jagung (N0:0 $\mathrm{kg} \mathrm{N} \mathrm{ha}^{-1}$; $\mathrm{N} 2: 200 \mathrm{~kg} \mathrm{~N} \mathrm{ha}^{-1}$ ). Huruf yang sama pada bartidak berbeda nyata pada uji BNJ taraf $5 \%$.

Hasil produksi jagung pada sistem T0 pada penelitian kali ini lebih rendah dibandingkan T1, hal ini dapat dikarenakan tingkat kekerasan tanah pada sistem TOT. Berdasarkan hasil penelitian jangka panjang yang dilakukan sejak 1987 menunjukkan kekerasan tanah T0 setelah 25 tahun cenderung lebih tinggi dari pada T2, hal ini menyebabkan sulitnya akar tanaman menembus tanah untuk mendapatkan nutrisi (Ardiansyah, Banuwa dan Utomo, 2015).

Hasil penelitian Utomo mengenai pengaruh pemupukan $\mathrm{N}$ dan sistem olah tanah jangka panjang (1987-2009) menunjukkan rerata produksi jagung TOT pada dosis $200 \mathrm{~kg} \mathrm{~N}^{-1}$ selama 22 tahun adalah $5,7 \mathrm{t} \mathrm{ha}^{-1}$ atau lebih tinggi $10 \%$ dibandingkan produksi jagung $\mathrm{T} 2$, sedangkan pada perlakuan tanpa $\mathrm{N}$ produksi jagung TOT sama dengan T2 yaitu 3,6 t ha ${ }^{-1}$ dan T1 3,3 t ha ${ }^{-1}$ (Utomo, 2015). Hal ini menunjukkan bahwa serapan hara pada T0 lebih optimal dibandingkan T2. Adanya 
mulsa pada lahan OTK tidak hanya berguna untuk meningkatkan serapan hara tanaman, tapi juga mampu menekan pertumbuhan gulma sehingga OTK mampu menghasilkan produksi jagung lebih tinggi dibandingkan T2 (Utomo, Suprapto. dan Sunyoto, 1989).

Perlakuan sistem olah tanah tidak berpengaruh nyata terhadap hasil brangkasan tanaman jagung, namun pemupukan $\mathrm{N}$ berpengaruh terhadap pertumbuhan tanaman sehingga brangkasan pada tanaman jagung yang diberi pupuk $\mathrm{N}$ lebih baik dibandingkan tanpa pupuk $\mathrm{N}$. Nitrogen merupakan unsur hara penting yang sangat dibutuhkan tanaman jagung, kandungan $\mathrm{N}$ tanah pada penelitian ini relatif rendah, sehingga pemberian $\mathrm{N}$ dari pupuk mampu meningkatkan pertumbuhan jagung. Adanya penambahan $\mathrm{N}$ dari pupuk dapat meningkatkan ketersediaan $\mathrm{N}$ dan mengurangi dampak imobilisasi $\mathrm{N}$ (Utomo, Suprapto. dan Sunyoto, 1989).

\section{Serapan Hara Makro Tanaman Jagung}

Hasil analisis ragam (Tabel 3) menunjukkan bahwa pemupukan $\mathrm{N}$ berpengaruh nyata pada seluruh serapan hara makro tanaman jagung namun hasil berbeda diperoleh pada serapan hara S. Perlakuan serapan hara S tidak hanya dipengaruhi oleh satu faktor, tetapi serapan hara $S$ dipengaruhi adanya interaksi antara perlakuan sistem olah tanah dan pemupukan N (Tabel 4). Hasil penelitian jangka panjang selama 29 tahun (meskipun pada penelitian ini sistem olah tanah tidak berpengaruh terhadap serapan hara makro), nyatanya serapan hara makro tertinggi seluruhnya terdapat pada perlakuan kombinasi pemupukan $\mathrm{N}$ tinggi dengan sistem olah tanam minimum jangka panjang (N2T1).

Berdasarkan hasil analisis ragam pemupukan nitrogen nyata berpengaruh terhadap serapan hara N, P, Ca dan K tanaman jagung, sedangkan aplikasi olah tanah tidak mempengaruhi tanaman jagung dalam penyerapan hara-hara tersebut (Tabel 3). Serapan hara N, P, Ca dan K tertinggi terdapat pada perlakuan N2 (200 kg $\mathrm{N}$ ha $^{-1}$ ) berturut-turut sebesar 50,97; 20,85; 29,51 dan $175,15 \mathrm{~kg} \mathrm{ha}^{-1}$ (Gambar 2). Selain itu hasil penelitian ini menunjukkan bahwa perlakuan olah tanah minimum yang dikombinasikan dengan $200 \mathrm{~kg}^{-1}$ pupuk $\mathrm{N}$ menghasilkan serapan hara $\mathrm{N}, \mathrm{P}, \mathrm{Ca}$ dan $\mathrm{K}$ tanaman jagung lebih tinggi dibandingkan perlakuan kombinasi lainnya (Tabel 3).

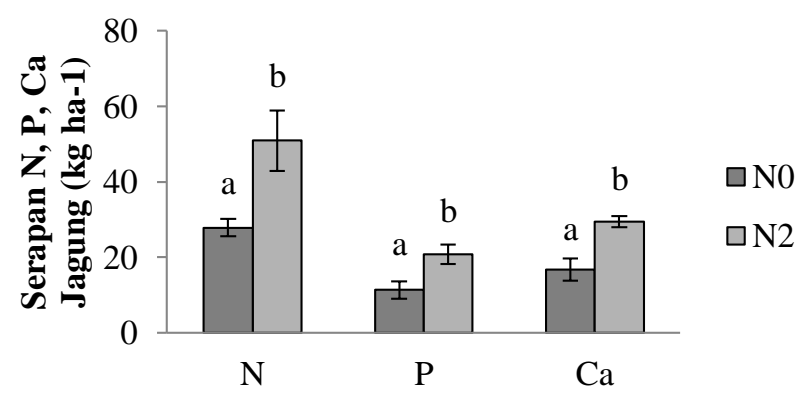

Gambar 2. Pengaruh perlakuan pemupukan nitrogen terhadap serapan hara $N, P, C a$ tanaman jagung (N0:0 $\mathrm{kg} \mathrm{N} \mathrm{ha}^{-1} ; \mathrm{N} 2: 200 \mathrm{~kg} \mathrm{~N} \mathrm{ha}^{-1}$ ). Huruf yang sama pada bartidak berbeda nyata pada uji BNJ taraf $5 \%$.

Tabel 3. Pengaruh pemupukan nitrogen dan sistem olah tanah jangka panjang terhadap serapan hara makro tanaman jagung. 


\begin{tabular}{|c|c|c|c|c|c|c|}
\hline \multirow[t]{2}{*}{ Perlakuan } & $\mathbf{N}$ & $\mathrm{P}$ & $\mathrm{K}$ & $\mathrm{Ca}$ & $\mathrm{Mg}$ & $\mathrm{S}$ \\
\hline & \multicolumn{6}{|c|}{$\left(\mathrm{kg} \mathrm{ha}^{-1}\right)$} \\
\hline N0T2 & 30,40 & 11,28 & 104,19 & 18,95 & 0,28 & 0,36 \\
\hline N0T1 & 27,39 & 13,68 & 135,95 & 17,80 & 0,25 & 0,31 \\
\hline NOTO & 25,78 & 9,09 & 92,75 & 13,45 & 0,19 & 0,36 \\
\hline N2T2 & 48,24 & 19,17 & 134,27 & 27,98 & 0,40 & 0,81 \\
\hline N2T1 & 59,95 & 23,87 & 201,87 & 30,90 & 0,52 & 1,37 \\
\hline N2TO & 44,71 & 19,50 & 189,31 & 29,66 & 0,32 & 1,25 \\
\hline $\mathrm{N}$ & $34,49^{* *}$ & $27,68^{* *}$ & $13,40^{* *}$ & $10,68^{* *}$ & $9,56^{* *}$ & $128,14^{\star *}$ \\
\hline $\mathrm{T}$ & $1,53 \mathrm{tn}$ & $2,28 \mathrm{tn}$ & 2,69 tn & $0,17 \mathrm{tn}$ & $1,68 \mathrm{tn}$ & $5,32^{*}$ \\
\hline $\mathrm{N}^{*} \mathrm{~T}$ & $1,44 \mathrm{tn}$ & 0,20 tn & 1,20 tn & $0,28 \mathrm{tn}$ & $0,63 \mathrm{tn}$ & $6,60^{\star *}$ \\
\hline
\end{tabular}

Keterangan : ${ }^{*}$ : berbeda nyata pada taraf $5 \% ;{ }^{* *}$ : berbeda nyata pada taraf $1 \%$; th : tidak berbeda nyata pada taraf $5 \% ; \pm$ : standar deviasi; T2 : Olah tanah intensif; T1 : Olah tanah minimum; T0 : Tanpa olah tanah; N0 : $0 \mathrm{~kg} \mathrm{~N} \mathrm{ha}^{-1}$; N2 : $200 \mathrm{~kg} \mathrm{~N}$ ha-
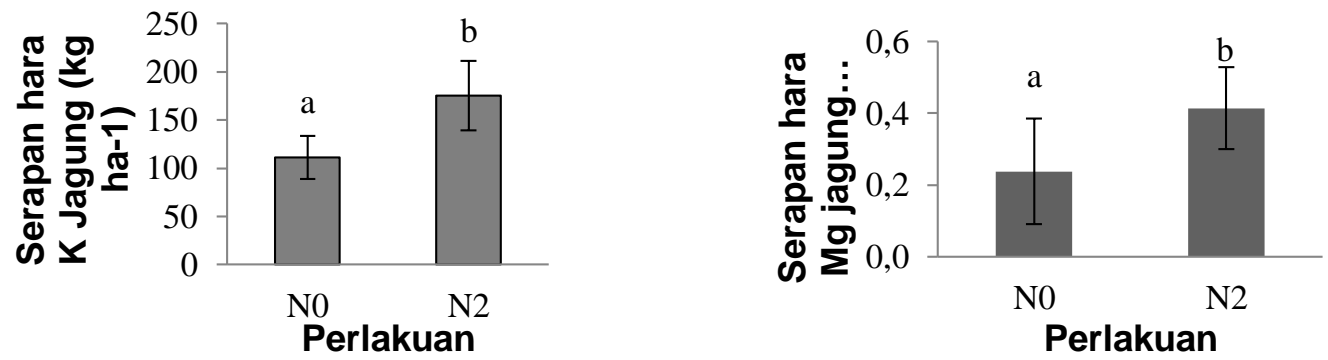

Gambar 3.Pengaruh perlakuan pemupukan nitrogen terhadap serapan hara $\mathrm{K}$ dan $\mathrm{Mg}$ brangkasan tanaman jagung (N0 : $0 \mathrm{~kg} \mathrm{~N}$ ha $^{-1}$; N2 : $200 \mathrm{~kg} \mathrm{~N}$ ha $^{-1}$ ). Huruf yang sama pada bartidak berbeda nyata pada uji BNJ taraf $5 \%$.

Hasil analisis ragam menunjukkan sistem olah tanah tidak berpengaruh terhadap penyerapan hara $\mathrm{Mg}$ tanaman. Namun pemupukan $\mathrm{N}$ nyata berpengaruh terhadap serapan hara $\mathrm{Mg}$ tanaman, perlakuan N2T1 $\left(200 \mathrm{~kg} \mathrm{~N} \mathrm{ha}^{-1}+\right.$ olah tanah minimum) menghasilkan rata-rata serapan hara $\mathrm{Mg}$ tertinggi dibandingkan kombinasi perlakuan lainnya sebesar $0,52 \mathrm{~kg} \mathrm{ha}^{-1}$. Berdasarkan hasil uji BNJ pada taraf 0,05 serapan hara $\mathrm{Mg}$ dan $\mathrm{Na}$ tertinggi terdapat pada perlakuan $\mathrm{N} 2$ (200 kg N ha ${ }^{-1}$ ) sebesar 2,06 kg ha-1 dan 401,55 g ha ${ }^{-1}$ (Gambar 3). Hasil uji BNJ 5\% menunjukkan pemberian pupuk $200 \mathrm{~kg} \mathrm{~N}^{-1}$ menghasilkan serapan S lebih tinggi dibandingkan kontrol di seluruh perlakuan sistem olah tanah. Sedangkan seluruh perlakuan sistem olah tanah tanpa pemupukan memiliki hasil serapan $S$ yang tidak berbeda. Selanjutnya perlakuan sistem olah tanah minimum dan tanpa olah tanah menghasilkan serapan hara $S$ yang lebih baik dibandingkan perlakuan olah tanah intensif jika dikombinasikan dengan pemupukan $200 \mathrm{~kg} \mathrm{~N} \mathrm{ha}^{-1}$ (Tabel 4).

Tabel 4. Pengaruh pemupukan nitrogen dan sistem olah tanah jangka panjang terhadap serapan hara $S$ tanaman jagung. 


\begin{tabular}{cccc}
\hline & T2 & T1 & T0 \\
\cline { 2 - 4 } & & $\mathbf{( k g ~ h a}^{-1} \mathbf{~}$ & \\
\hline $0 \mathrm{~kg} \mathrm{~N} \mathrm{ha}^{-1}$ & $0,35 \mathrm{a}$ & $0,31 \mathrm{a}$ & $0,36 \mathrm{a}$ \\
$200 \mathrm{~kg} \mathrm{~N} \mathrm{ha}^{-1}$ & $\mathrm{~A}$ & $\mathrm{~A}$ & $\mathrm{~A}$ \\
& $0,81 \mathrm{a}$ & $1,37 \mathrm{~b}$ & $1,25 \mathrm{~b}$ \\
\hline BNJ 5\% & $\mathrm{B}$ & $\mathrm{B}$ & $\mathrm{B}$ \\
\hline
\end{tabular}

Keterangan: T2 : Olah tanah intensif; T1 : Olah tanah minimum; T0 : Tanpa olah tanah. Angka-angka yang diikuti huruf yang sama, huruf kecil untuk baris dan huruf besar untuk kolom, tidak berbeda menurut uji BNJ $5 \%$.

\section{Serapan Hara Mikro Tanaman Jagung}

Hasil analisis ragam menunjukkan bahwa perlakuan pemupukan $N$ berpengaruh terhadap seluruh serapan hara mikro tanaman jagung, sedangkan perlakuan olah tanah jangka panjang tidak berpengaruh nyata terhadap serapan hara mikro tanaman jagung, kecuali hara $B$ dan tidak terdapat interaksi pada kedua perlakuan. Dari hasil penelitian diperoleh pemupukan $\mathrm{N}$ yang dikombinasikan dengan sistem olah tanah minimum menghasilkan serapan hara mikro tertinggi pada seluruh perlakuan kecuali hara Fe dengan hasil serapan tertinggi terdapat pada perlakuan N2T0 (Tabel 5).

Berdasarkan hasil uji BNJ pada taraf 0,05 serapan hara $\mathrm{Zn}$ tertinggi terdapat pada perlakuan N2 (200 kg N ha-1) sebesar 462,14 $\mathrm{g} \mathrm{ha}^{-1}$ (Gambar 4). Sedangkan pada uji analisis ragam menunjukkan perlakuan olah tanah tidak berpengaruh terhadap serapan hara $\mathrm{Zn}$ begitupun interaksinya dengan perlakuan pemupukan (Tabel 5). Berdasarkan hasil uji BNJ pada taraf 0,05 pemupukan nitrogen berpengaruh terhadap serapan hara Fe brangkasan tanaman jagung (Gambar 4). Serapan Fe tertinggi terdapat pada kombinasi perlakuan N2TO (200 kg N ha ${ }^{-1}+$ tanpa olah tanah) sebesar 5136,12 $\mathrm{g} \mathrm{ha}^{-1}$ (Tabel 5). Besi merupakan unsur mikro yang diserap dalam bentuk ion feri $\left(\mathrm{Fe}^{3+}\right)$ atau fero $\left(\mathrm{Fe}^{2+}\right)$ sedangkan $\mathrm{Zn}$ diserap tanaman dalam bentuk $\mathrm{Zn}^{2+}$.

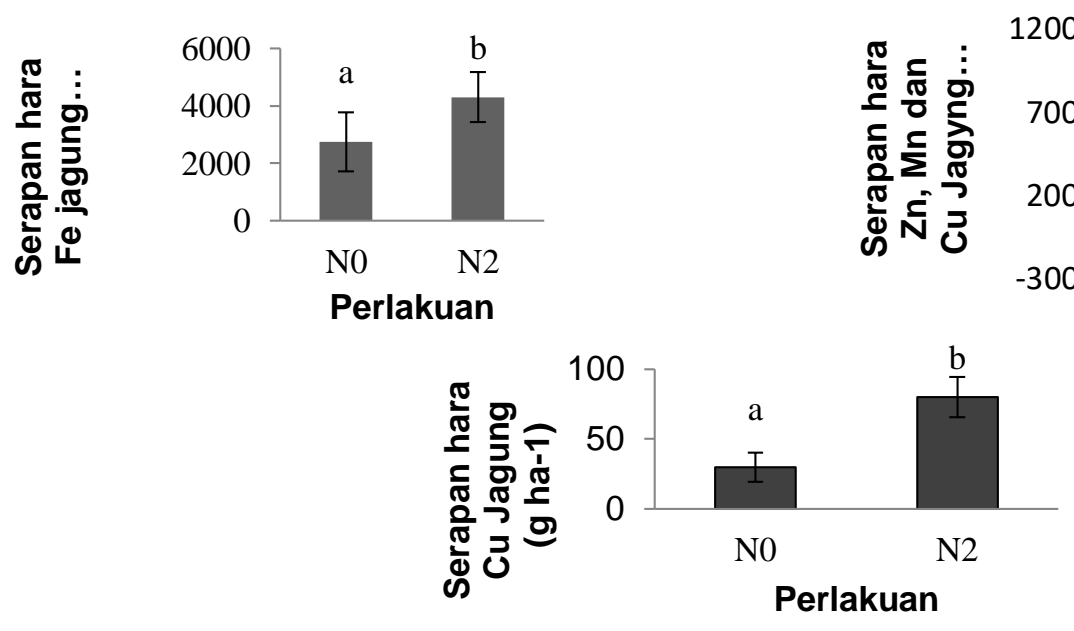

Gambar 4.Pengaruh perlakuan pemupukan nitrogen terhadap serapan hara $\mathrm{Fe}, \mathrm{Zn}, \mathrm{Mn}, \mathrm{B}$ dan $\mathrm{Cu}$ tanaman jagung (N0 : $0 \mathrm{~kg} \mathrm{~N} \mathrm{ha}^{-1} ; \mathrm{N} 2: 200 \mathrm{~kg} \mathrm{~N}^{-1}$ ). Huruf yang sama pada bar tidak berbeda nyata pada uji BNJ taraf $5 \%$.

Hasil analisis ragam menyatakan bahwa perlakuan pupuk nitrogen dan aplikasi berbagai sistem olah tanah jangka panjang berpengaruh nyata terhadap serapan hara $\mathrm{Mn}$ dan $\mathrm{B}$ tanaman jagung, meskipun tidak terdapat interaksi (Tabel 5). Hasil 
uji BNJ 0,05 menunjukkan bahwa pada perlakuan pemupukan nitrogen tinggi (N2) menghasilkan serapan hara $\mathrm{Mn}$ dan $\mathrm{B}$ tanaman jagung lebih tinggi dibandingkan perlakuan N0 sebesar $910,67 \mathrm{~g} \mathrm{ha}^{-1}$. Sedangkan pada perlakuan aplikasi sistem olah tanah, serapan hara Mn tertinggi terdapat pada perlakuan T1 sebesar 720,28 g ha $^{-1}$, hasil ini tidak berbeda dengan perlakuan T2 dengan serapan Mn sebesar $648,14 \mathrm{~g} \mathrm{ha}^{-1}$ (Gambar 7).
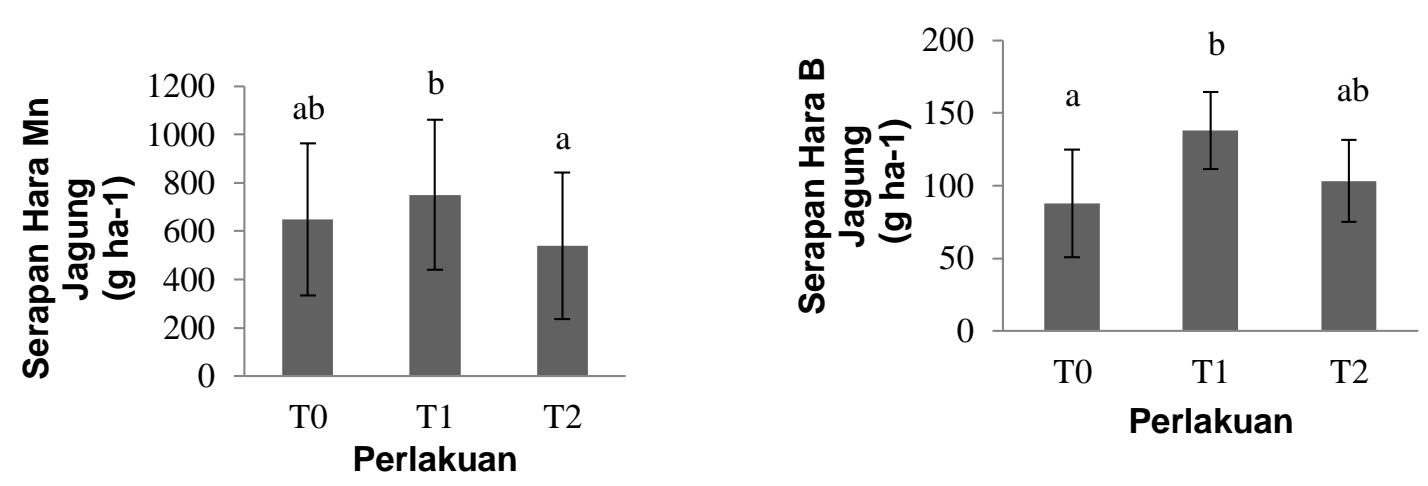

Gambar 5. Pengaruh perlakuan olah tanah jangka panjang terhadap serapan hara Mn dan B tanaman jagung (T2 : Olah tanah intensif; T1 : Olah tanah minimum; T0 : Tanpa olah tanah). Huruf yang sama pada bar tidak berbeda nyata pada uji BNJ taraf $5 \%$.

Berdasarkan hasil analisis ragam menunjukkan bahwa perlakuan pemberian pupuk nitrogen berpengaruh nyata terhadap serapan hara B dan $\mathrm{Cu}$ tanaman jagung, sedangkan perlakuan sistem olah tanah yang berpengaruh nyata hanya terdapat pada serapan hara B (Tabel 5). Hasil uji BNJ pada taraf 0,05 menunjukkan bahwa pada perlakuan pemupukan nitrogen tinggi (N2) menghasilkan serapan hara B tanaman jagung lebih tinggi dibandingkan perlakuan No $\left(0 \mathrm{~kg} \mathrm{~N} \mathrm{ha}^{-1}\right)$ sebesar $126,00 \mathrm{~g} \mathrm{ha}^{-1}$. Sedangkan pada perlakuan aplikasi sistem olah tanah, serapan hara B tertinggi terdapat pada perlakuan T1 (olah tanah minimum) sebesar $275,98 \mathrm{~g} \mathrm{ha}^{-1}$, hasil ini tidak berbeda dengan perlakuan T0 (tanpa olah tanah) dengan serapan B sebesar 206,48 g ha ${ }^{-1}$ (Gambar 13). Sedangkan hasil uji BNJ taraf 0,05 menunjukkan serapan hara Cu brangkasan tanaman jagung tertinggi terdapat pada perlakuan N2 (200 kg N ha-1) sebesar 79,82 $\mathrm{g} \mathrm{ha}^{-1}$, sedangkan serapan hara pada perlakuan N0 (sebesar 29,54 $\mathrm{g} \mathrm{ha}^{-1}$ (Gambar 5).

Hasil penelitian jangka panjang selama 29 tahun secara berturut-turut menunjukkan bahwa serapan hara makro dan mikro tertinggi terdapat pada perlakuan olah tanah konservasi (OTK). Serapan hara makro tertinggi seluruhnya terdapat pada perlakuan kombinasi N2T1 (200 kg N ha-1 + olah tanah minimum), sedangkan serapan hara makro terendah terdapat pada perlakuan olah tanah intensif (Tabel 3). Hasil analisis ragam terhadap serapan hara mikro menunjukkan pelakuan N2T0 memiliki serapan hara lebih baik dibandingkan N2T2 $\left(200 \mathrm{~kg} \mathrm{~N} \mathrm{ha}^{-1}+\right.$ olah tanah intensif) (Tabel 5).

Tabel 5. Pengaruh pemupukan nitrogen dan sistem olah tanah jangka panjang terhadap serapan hara mikro tanaman jagung.

\begin{tabular}{llllll} 
Perlakuan & Fe & Mn & Zn & B & Cu \\
\hline
\end{tabular}




\begin{tabular}{cccccc}
\hline & \multicolumn{5}{c}{$\mathbf{( g ~ h a ~}^{-1} \mathbf{)}$} \\
\hline N0T2 & 3349 & 398,34 & 249,14 & 60,53 & 32,37 \\
N0T1 & 2352 & 472,08 & 262,27 & 120,93 & 33,51 \\
N0T0 & 2541 & 274,20 & 195,85 & 98,56 & 22,74 \\
N2T2 & 3983 & 897,93 & 367,34 & 115,02 & 66,79 \\
N2T1 & 3806 & 1028,48 & 428,96 & 155,05 & 87,86 \\
N2T0 & 5136 & 805,59 & 339,20 & 107,93 & 84,80 \\
N & $16,21^{\star *}$ & $78,96^{* \star}$ & $20,83^{* \star}$ & $8,31^{* *}$ & $105,76^{\star *}$ \\
T & 1,40 tn & $4,16^{*}$ & 2,07 tn & $6,87^{* *}$ & 1,75 tn \\
N $^{*}$ T & 2,14 tn & 0,07 tn & 0,20 tn & 1,32 tn & 2,83 tn \\
\hline
\end{tabular}

Keterangan: *: berbeda nyata pada taraf $5 \%$; ${ }^{* *}$ : berbeda nyata pada taraf $1 \%$; tn : tidak berbeda nyata pada taraf $5 \% ; \pm$ : standar deviasi; T2 : Olah tanah intensif; T1 : Olah tanah minimum; T0 : Tanpa olah tanah; N0 : $0 \mathrm{~kg} \mathrm{~N} \mathrm{ha}^{-1}$; N2 : $200 \mathrm{~kg} \mathrm{~N} \mathrm{ha}^{-1}$.

Pada setiap 1 ton brangkasan kering jagung terkandung hara $\mathrm{N}, \mathrm{P}, \mathrm{K}$ berturutturut sebesar 10; 1,72 dan 12,27 kg ha ${ }^{-1}$ (Clark, Jennifer dan Chapman, 1985). Hasil tersebut lebih besar apabila dibandingkan pada perlakuan N2T1 dalam penelitian ini yaitu sebesar $5,79 \mathrm{~kg} \mathrm{ha}^{-1}$, sedangkan serapan $\mathrm{P}$ dan $\mathrm{K}$ pada perlakuan $\mathrm{N} 2 \mathrm{~T} 1$ menunjukkan serapan hara yang lebih tinggi dengan nilai berturut-turut 2,30 dan $19,52 \mathrm{~kg} \mathrm{ha}^{-1}$. Sementara itu kebutuhan hara makro N, P, K, Ca, Mg, S pada setiap 1 ton batang jagung berturut-turut 6,$56 ; 0,84 ; 16,61 ; 4,12 ; 3,49 ; 0,95 \mathrm{~kg} \mathrm{ha}^{-1}$, sedangkan hara mikro $\mathrm{Fe}, \mathrm{Mn}, \mathrm{Cu}, \mathrm{Zn}, \mathrm{B}$ yang terserap pada setiap 1 ton biji jagung berturut-turut 0,$21 ; 0,029 ; 0,095 ; 0,02 ; 0,014 \mathrm{~kg} \mathrm{ha}^{-1}$ (Syafruddin, Faessal dan Akil, 2006). Hal ini menunjukkan bahwa serapan hara jagung pada penelitian ini belum mencukupi standart serapan hara yang seharusnya, diperlukan penambahan hara tersedia dalam tanah yang dapat diserap tanaman sehingga produksi yang dihasilkan bisa lebih optimal. Perlakuan sistem olah tanah konservasi secara jangka panjang memiliki banyak keunggulan, tidak hanya dalam mempertahankan produktivitas tanaman agar menjadi optimal tapi juga dalam menjaga kesuburan dan kesehatan tanah. Penggunaan mulsa pada sistem OTK juga bermanfaat sebagai penutup tanah dan sebagai penyuplai unsur hara jika bahan organik tanah telah terdekomposisi.

Berkenaan dengan manfaat mulsa bagi tanah dan tanaman, untuk menurunkan evaporasi dapat dengan penebaran bahan mulsa dipermukaan tanah, selain menurunkan evaporasi, mulsa juga dapat meningkatkan penahanan air bagi tanah pada saat hujan. Selain itu kelebihan pemakaian mulsa dapat menurunkan kehilangan air dari tanah, juga mampu menurunkan erosi hingga pada kemiringan tanah mencapai 50\% (Lumbanraja, 1997). Penggunaan mulsa sangat efektif dalam menurunkan erosi. Selain mengurangi erosi penggunaan mulsa juga mempengaruhi suhu tanah, kemampuan tanah menahan air, kekuatan penetrasi, kemantapan agregat dan aerasi (Cooke, 1985).

Pemupukan penting dilakukan sebagai penyuplai unsur hara tersedia bagi tanaman. Pemberian pupuk $\mathrm{N}$ tidak hanya menjadi sumber hara bagi tanaman, tapi dapat berperan untuk melepaskan ion-ion dalam tanah. Tanah memiliki mineralmineral terikat yang apabila dilepaskan dapat menjadi unsur hara tersedia bagi tanaman. Pemberian pupuk $\mathrm{N}$ tinggi dapat meningkatkan konsentrasi $\mathrm{N}$ didalam tanah dalam bentuk $\mathrm{NH}_{4}{ }^{+}$, sehingga ion $\mathrm{Ca}^{2+}, \mathrm{Mg}^{2+}, \mathrm{Fe}^{3+}, \mathrm{Mn}^{2+}$ dan $\mathrm{Na}^{+}$akan terusir dari koloid tanah dan digantikan dengan $\mathrm{NH}_{4}{ }^{+}$. Dengan terlepasnya ion tersebut dari koloid tanah, maka akan tersedia dan dapat diserap oleh tanaman melalui mekanisme aliran massa. Hal ini sejalan dengan ungkapan [2,10] yang menyatakan bahwa tingginya konsentrasi $\mathrm{NH}_{4}{ }^{+}$yang dimasukkan ke dalam kolom tanah, akan 
menyebabkan pertukaran anion dan kation. Sehingga anion dan kation yang terikat didalam kolom tanah akan terlepas dan digantikan dengan $\mathrm{NH}_{4}{ }^{+}$. Mekanisme ini juga berdampak pada efisensi hara yang diserap oleh tanaman, karena pemberian pupuk $\mathrm{N}$ secara tidak langsung membantu tanah dalam menyediakan unsur hara lain yang tidak diberikan pada proses pemupukan tanaman.

Pertukaran kation merupakan mekanisme yang menentukan ion-ion terikat dapat tersedia bagi tanaman. Selain pemberian pupuk $\mathrm{N}, \mathrm{pH}$ tanah yang rendah juga sangat berpengaruh dalam proses pelapukan mineral tanah. Tanah Ultisol dalam penelitian ini termasuk dalam kategori tanah dengan $\mathrm{pH}$ rendah yang memiliki kandungan $\mathrm{H}^{+}$tinggi, penggunaan tanah sebagai media tanam secara terus menerus juga dapat menurunkan $\mathrm{pH}$ tanah akibat pelepasan ion $\mathrm{H}^{+}$pada saat akar tanaman menyerap usur hara. Menurut (Salam, 2012) ion $\mathrm{H}^{+}$yang banyak terdapat dalam sistem tanah akan berperan sebagai attacking agent yang mampu menghancurkan struktur mineral tanah sehingga dapat membebaskan unsur hara kedalam air tanah. Seluruh proses ini juga berpengaruh dalam meningkatkan efisiensi penyerapan unsur hara pada tanaman karena tanah tidak hanya menjadi media tanam tapi dapat menjadi sumber hara tersedia bagi tanaman sehingga penggunaan pupuk kimia dapat dikurangi.

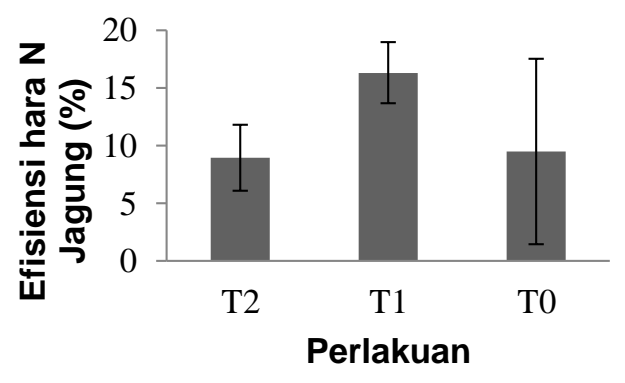

Gambar 6. Efisiensi serapan hara N tanaman jagung pada tiga praktik olah tanah (T2 : Olah tanah intensif; T1 : Olah tanah minimum; T0 : Tanpa olah tanah).

\section{Efisiensi $N$}

Efisiensi hara diuji untuk melihat pengaruh sistem olah tanah terhadap persen serapan hara yang dimanfaatkan tanaman untuk pertumbuhan, dengan melihat perlakuan pemupukan $\mathrm{N}$ yang diberikan. Berdasarkan hasil analisis ragam pengaruh perlakuan pemupukan nitrogen dan olah tanah jangka panjang terhadap efisiensi hara $\mathrm{N}$ brangkasan tanaman jagung menunjukkan aplikasi olah tanah minimum (T1) menghasilkan efisiensi hara tertinggi yakni sebesar $16,28 \%$ dari pupuk yang diberikan (Gambar 6). Hal ini menunjukkan bahwa aplikasi olah tanah minimum mampu meminimalisir kehilangan hara $\mathrm{N}$ didalam tanah, terbukti efisiensi hara $\mathrm{N}$ pada T1 lebih tinggi dibandingkan perlakuan lainnya. Penelitian Utomo, (1995) yang menunjukkan rerata efisiensi pemupukan $\mathrm{N}$ tanaman jagung pada lahan tanpa olah tanah mencapai 37,8\% apabila dibandingkan dengan olah tanah intensif yang hanya mencapai $16,6 \%$ pada dua musim tanam di tahun pertama, selanjutnya serapan hara pada lahan OTK dengan dosis $\mathrm{N}$ optimum lebih tinggi apabila dibandingkan dengan lahan T2. Sedangkan pada penelitian ini sistem T1 menunjukkan efisiensi N yang lebih tinggi dibandingkan TOT, hal ini dapat terjadi akibat pemadatan tanah yang terjadi pada lahan TOT. Berdasarkan hasil penelitian jangka panjang menunjukkan interaksi antara sistem olah tanah dan residu pupuk tidak berpengaruh pada $\mathrm{N}$-total tanah. Hal ini diduga pada penelitian olah tanah konservasi jangka panjang tahun ke- 
29 tanah sudah mulai mengalami pemadatan (kekerasan) yang mengakibat aerasi tanah kurang baik (Kusumastuti et al. 2018).

Pengolahan tanah terlalu sering dapat menyebabkan tanah menjadi lebih gembur dan terbuka dalam waktu lama, sehingga meningkatkan laju evapotranspirasi dan mengurangi daya pegang tanah terhadap air. Ketersediaan air dalam tanah sangat mempengaruhi pertumbuhan tanaman, dimana air yang digunakan oleh tanaman merupakan air tersedia yang terdapat didalam pori-pori tanah pada lapisan perakaran tanaman, air juga berperan dalam proses pelapukan mineral dan pelarut unsur hara agar mudah diserap tanaman. Ketersediaan air tanah dan pengembalian bahan organik melalui mulsa sangat membantu dalam meningkatkan penyerapan hara oleh tanaman (Wahyunie, Baskoro dan Sofyan, 2012).

\section{Relative Agronomic Effectiveness (RAE)}

Tabel 6. Pengaruh pemupukan nitrogen dan sistem olah tanah jangka panjang terhadap nilai RAE (Relative Agronomic Effectiveness) tanaman jagung.

\begin{tabular}{lc}
\hline Perlakuan & $R A E$ \\
& $\left(\mathrm{~kg} \mathrm{jagung} \mathrm{kg} \mathrm{N}^{-1}\right)$ \\
\hline Olah Tanah Intensif & 3,50 \\
OlahTanah Minimum & 9,50 \\
Tanpa Olah Tanah & 19,50 \\
\hline
\end{tabular}

Berdasarkan hasil uji Relative Agronomic Effectiveness (RAE) yang telah dilakukan terhadap perlakuan pemberian pupuk $\mathrm{N}$ dan berbagai sistem olah tanah menunjukkan bahwa RAE tertinggi terdapat pada perlakuan T0 (tanpa olah tanah) sebesar 19,50 kg jagung kg N${ }^{-1}$. Hal tersebut menunjukkan bahwa pada setiap $1 \mathrm{~kg}$ $\mathrm{N}$ yang diberikan mampu menghasilkan pipilan jagung sebanyak $19,50 \mathrm{~kg}$. Hasil ini lima kali lipat lebih besar dibandingkan RAE pada olah tanah intensif yaitu sebesar $3,50 \mathrm{~kg}$ jagung $\mathrm{kg} \mathrm{N}^{-1}$ (Tabel 6).

Pupuk $\mathrm{N}$ yang diberikan pada sistem tanpa olah tanah jangka panjang mampu meningkatkan efektivitas produksi tanaman jagung. Hal tersebut tidak terlepas dari kemampuan tanaman dalam menyerap unsur hara untuk pertumbuhan dan produksinya yang didukung oleh faktor lingkungan sebagai akibat dari penerapan sistem tanpa olah tanah jangka panjang. Pengembalian bahan organik berupa mulsa pada lahan pertanaman menciptakan lingkungan yang mendukung tanaman untuk tumbuh normal. Ketersedian air, porositas tanah, pemberian pupuk dan faktor lingkungan lainnya pada penelitian ini mampu menunjang tanaman dalam tumbuh secara optimal.

Hal ini sejalan dengan produksi tanaman jagung pada penelitian ini. Berdasarkan uji BNJ 5\% produksi jagung tertinggi terdapat pada olah tanah minimum namun tidak berbeda dengan perlakuan tanpa olah tanah. Sedangkan pada serapan hara dan efisiensi tanaman jagung perlakuan pupuk N $200 \mathrm{~kg} \mathrm{ha}^{-1}$ dengan olah tanah konservasi menghasilkan serapan dan efisensi hara terbaik. Hal tersebut menunjukkan bahwa pemberian pupuk $\mathrm{N}$ dapat lebih optimal jika dikombinasikan dengan perlakuan tanpa olah tanah baik dilihat dari segi produksi maupun biaya.

RAE adalah persentase kenaikan hasil penggunaan suatu pupuk dibandingkan dengan persentase hasil pada penggunaan pupuk standar atau rekomendasi. RAE menunjukan seberapa efektif pupuk yang diberikan dibandingkan dengan pupuk standar. Nilai RAE penggunaan pupuk standar adalah 100\%, sehingga penggunaan pupuk dikatakan efektif jika nilai RAE lebih dari 100\% (Subandi, Hasani dan, 2016). 
Hasil penelitian pada tanah yang diolah sebelum penanaman jagung yang dikombinasikan dengan pupuk kimia NP standar menghasilkan RAE sebesar $134 \%$, hasil tersebut lebih baik dibandingkan RAE pada dosis pupuk NP yang lebih rendah, walaupun sudah dikombinasikan dengan berbagai pupuk subtitusi seperti pupuk hayati dan pupuk organik [21].

\section{SIMPULAN}

Pemupukan $200 \mathrm{~kg} \mathrm{~N} \mathrm{ha}^{-1}$ menghasilkan serapan hara makro dan mikro, serta brangkasan tanaman jagung yang lebih tinggi dibandingkan kontrol $\left(0 \mathrm{~kg} \mathrm{~N} \mathrm{ha}^{-1}\right)$. Praktik olah tanah minimum jangka panjang dapat meningkatkan serapan hara mikro ( $B$ dan $\mathrm{Mn}$ ), lebih tinggi bila dibandingkan olah tanah intensif. Interaksi pemupukan $200 \mathrm{~kg} \mathrm{~N} \mathrm{ha}^{-1}$ dan olah tanah minimum menghasilkan produksi jagung dan serapan hara makro (S) lebih tinggi dibandingkan kombinasi pemupukan $\mathrm{N}$ dengan olah tanah intensif, namun sama dengan kombinasi pemupukan $\mathrm{N}$ dan sistem tanpa olah tanah. Praktik olah tanah minimum jangka panjang menghasilkan efisiensi hara Nitrogen lebih tinggi dibandingkan T0 maupun T2 sebesar 16,28\%. Pemberian pupuk $\mathrm{N} 200 \mathrm{~kg} \mathrm{~N} \mathrm{ha}^{-1}$ dan perlakuan praktik olah tanah jangka panjang menghasilkan nilai RAE untuk T2, T1 dan T0 berturut-turut sebesar 3,50, 9,50 dan 19,5 kg pipilan jagung per $1 \mathrm{~kg}$ pupuk $\mathrm{N}$.

\section{DAFTAR PUSTAKA}

Ardiansyah, R., I.S. Banuwa,dan M. Utomo. 2015. Pengaruh Sistem Olah Tanah dan Residu Pemupukan Nitrogen Jangka Panjang terhadap Struktur Tanah, Bobot Isi, Ruang Pori Total dan Kekerasan Tanah pada Pertanaman Kacang Hijau (Vigna radiata L.). Jurnal Agrotek Tropika 3(2) : 283-289.

Badan Pusat Statistik. 2015. Data Produktivitas Jagung Indonesia pada Tahun 2015 (http://www.bps.go.id). Diakses pada 8 Juli 2017.

Clark, E.H., A.H Jennifer dan W. Chapman. 1985. Eroding soils: The off farm impact. The conservation foundation. Washington D.C.

Cooke, G.W. 1985. Potassium in The Agricultural System of the Humid Tropics. Prosiding. 19th Colloqium of the International Potash Institute. Thailand. 21-28 hlm.

Habbib, H., J. Verzeaux., E. Nivelle., D. Roger, J. Lacoux., M. Catterou., B. Hirel., F. Dubols., dan T. Tetu. 2016. Conversion to No-Tillage Improves Maize Nitrogen Use Efficiency in a Continuous Cover Cropping System. Journal Plos One 11(10): $1^{-1} 6$.

Hardjowigeno, S. 2007. Ilmu Tanah. Akademi Pressindo. Jakarta. $288 \mathrm{hlm}$.

Kusumastuti, A., Fatahillah., A. Wijaya., dan Y. Sukmawan. 2018. Pengaruh Sistem Olah Tanah dan Residu N Tahun ke-29 pada Beberapa Sifat Kimia Tanah dengan Tanaman Indikator Leguminosa. Journal of Applied Agricultural Sciences 2 (1): 20-29.

Lingga, P dan Marsono. 2008. Petunjuk Penggunaan Pupuk. Penebar Swadaya. Jakarta. $150 \mathrm{hlm}$.

Lumbanraja, P. 1997. Efek Aplikasi Terracottem, Pupuk Kandang dan Mulsa Jerami pada Alfisol Jonggol Terhadap Beberapa Sifat Fisik Tanah dan Hasil Tanaman 
Kedelai (Glycine max L) Varietas Tampomas. Majalah IImiah Universitas HKBP Nommensen. Pasca Sarjana Institut Pertanian Bogor (IPB). Bogor 5(2):22-43.

Mackay, A.D., J. K Syers., and P.E.H Gregg. 1984. Ability of Chemical Extraction Procedures to Assess The Agronomic Effectiveness of Phosphate Rock Materials. New Zealand. Journal of Agriculture Research 27: 219-230.

Napitupulu, D dan L. Winarto. 2010. Pengaruh Pemberian Pupuk N dan K terhadap Pertumbuhan dan Produksi Bawang Merah. Jurnal Hortikultura 20(1): 27-35.

Nurahmi, E. 2010. Kandungan Unsur Hara Tanah dan Tanaman Selada pada Tanah Bekas Tsunami Akibat Pemberian Pupuk Organik dan Anorganik. Universitas Syiah Kuala Darussalam Banda Aceh. Jurnal Floratek 5:74-85.

Prasetyo, B. H dan D.A Suriadikarta. 2006. Karakteristik, Potensi, dan Teknologi Pengelolaan Tanah Ultisol untuk Pengembangan Pertanian Lahan Kering di Indonesia. Jurnal Litbang Pertanian 25(2): 39 - 47.

Salam, A. K. 2012. IImu Tanah Fundamental. Global Madani Pres. Bandar Lampung. $362 \mathrm{hlm}$.

Subandi, M., S. Hasani dan W. Satriawan. 2016. Tingkat Efisiensi dan Efektivitas Pupuk Hayati dalam Mensubtitusi Pupuk Nitrogen dan Fosfor pada Tanaman Jagung (Zea mays L.). Jurnal Agrista 20 (3): $140^{-1} 49$.

Syafruddin, Faessal, dan M. Akil. 2006. Pengelolaan Hara pada Tanaman Jagung. Teknik Produksi dan Pengembangan Balai Penelitian Tanaman Serelia. 205$218 \mathrm{hlm}$.

Utomo, M. 2015. Tanpa Olah Tanah, Teknologi Pengelolaan Pertanian Lahan Kering. Penerbit Graha Ilmu. $157 \mathrm{hlm}$.

Utomo, M. 2012. Tanpa Olah Tanah: Teknologi Pengelolaan Pertanian Lahan Kering. Lembaga Penelitian Universitas Lampung. Bandar Lampung. $110 \mathrm{hlm}$.

Utomo, M., H. Suprapto dan Sunyoto. 1989. Influence of Tillage and Nitrogen Fertilization on Soil Nitrogen, Decomposition of Alang-Alang (Imperata cylindrical) and Corn Production of Alang-Alangldan. In :J. Van der Heide (ed.). Nutrition Management for Food Crop Production in Tropical Farming Systems. Institut for Soil Fertility (IB) pp. 367-373.

Utomo, M. 1995. Sistem Olah Tanah Konservasi dan Pertanian Berkelanjutan Sarasehan tentang Kebijakan Pertanian Berkelanjutan. Kantor Menteri Lingkungan Hidup. Jakarta.

Wahyunie, E. D., D.P.T Baskoro., dan M. Sofyan. 2012. Kemampuan Retensi Air dan Ketahanan Penetrasi Tanah pada Sistem Olah Tanah Intensif dan Olah Tanah Konservasi. Jurnal Tanah Lingkungan 14 (2): 73-78. 2012. 